A thematic paper supporting the OECD DAC INCAF project

'Global Factors Influencing the Risk of Conflict and Fragility'

\title{
Transnational organised crime and fragile states
}

Paula Miraglia, Rolando Ochoa and Ivan Briscoe

International Center for the Prevention of Crime and the Clingendael Institute

OECD DEVELOPMENT CO-OPERATION

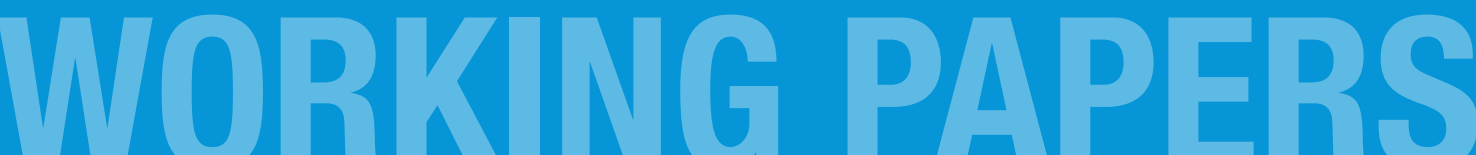

The Development Assistance Committee: Enabling effective development 
This work is published on the responsibility of the Secretary-General of the Organisation for Economic Cooperation and Development (OECD). The opinions expressed and arguments employed herein do not necessarily reflect the official views of the Organisation or of the governments of its member countries.

This document and any map included herein are without prejudice to the status of or sovereignty over any territory, to the delimitation of international frontiers and boundaries and to the name of any territory, city or area.

\section{Note to the reader}

This paper is one of eight thematic papers supporting the OECD DAC INCAF project on Global Factors Influencing the Risk of Conflict and Fragility. Each paper explores a specific global factor. The synthesis report, Think Global, Act Global: Confronting global factors influencing conflict and fragility (OECD, 2012), can be found at:

\section{www.oecd.org/dac/conflictandfragility/globalfactors.htm.}

While the thematic papers have been subjected to a robust peer review process, they remain working papers rather than for publication in peer-reviewed journals.

\section{Acknowledgements}

Paula Miraglia is Director General of the International Centre for the Prevention of Crime (ICPC). Rolando Ochoa is Senior Analyst at the ICPC. Ivan Briscoe is a Senior Research Fellow in governance at the Conflict Research Unit, Netherlands Institute of International Relations (Clingendael). The authors would like to thank Ann Fitz-Gerald (Cranfield University) and Erwin van Veen (OECD) for their support in coordinating this project and giving pointed and much needed feedback throughout. Our appreciation also goes to the peer reviewers for their excellent feedback and to the other members of the project for their help in refining and discussing the central ideas in this paper at a meeting at Cranfield University in the UK. Staff at ICPC also helped with research and gathering of material for the paper and our thanks go to them as well. 


\section{Abstract}

Transnational organised crime (TOC) refers to a fluid and diversified industry that engages in illicit activities ranging from drug and human trafficking to drug smuggling, piracy and money laundering. Although it may affect strong states, conflict-affected and fragile states are especially vulnerable to the dynamics of TOC and may provide more favourable conditions for its development. The implications for those states are many and serious. This paper outlines the ways in which TOC has evolved in recent years and how policy might be adapted to take account of this evolution. It emphasises that TOC today is less a matter of organised cartels established in producer or end-user states, but increasingly characterised by fluid, opportunistic networks that may for example specialise in transport and logistics. The paper recommends tackling the problem through a comprehensive approach that considers TOC as but one element within a greater complex of cause and effect. This would entail a re-evaluation of many current assumptions about TOC and a reformulation of current policies. 


\section{Table of Contents}

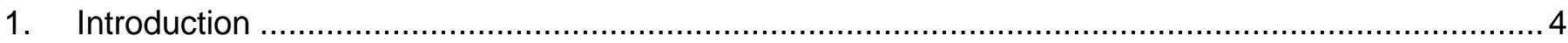

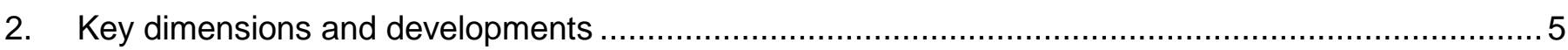

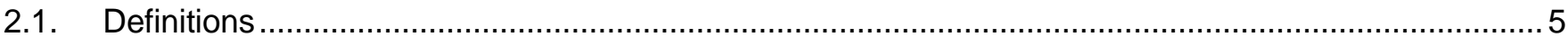

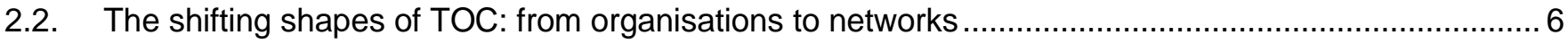

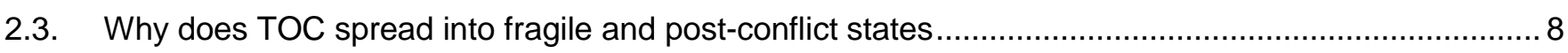

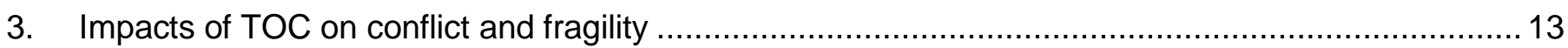

3.1. Eroding the state's capacity to deliver public goods ............................................................ 13

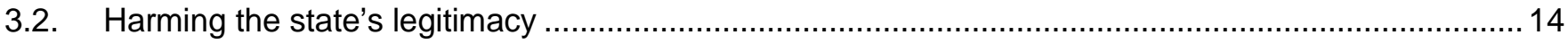

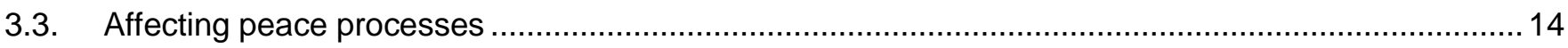

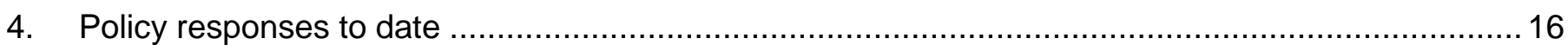

4.1. A more comprehensive approach to statebuilding by development agencies .............................. 16

4.2. A more integrated approach to peacekeeping missions .......................................................... 17

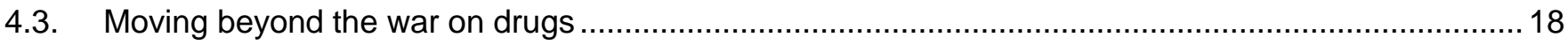

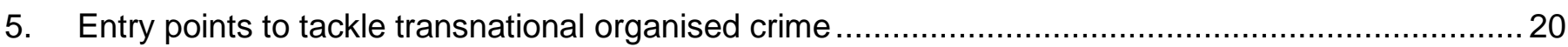

5.1. Co-operation and shared responsibility along the supply chain ...............................................20

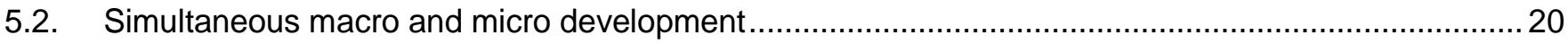

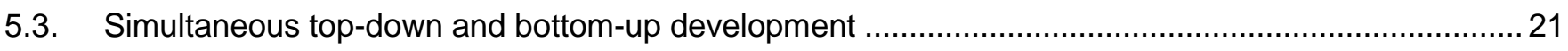

5.4. Peace operations based on better training and research .................................................... 21

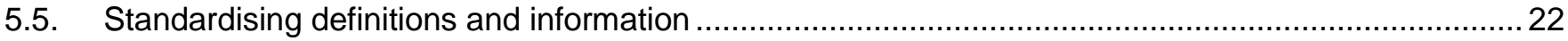

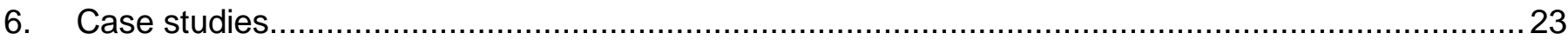

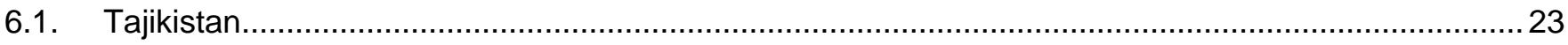

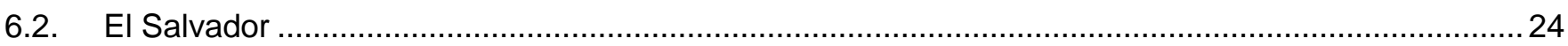

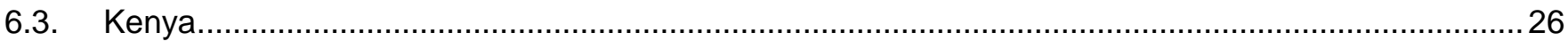

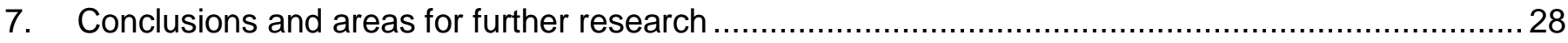

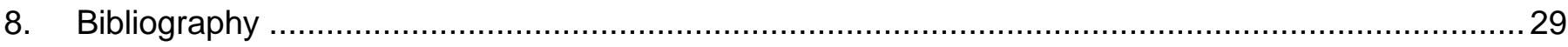

Boxes

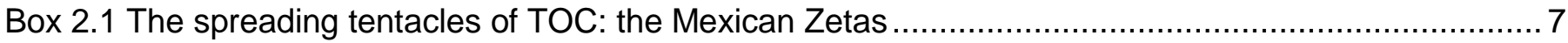

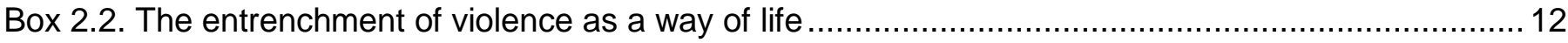

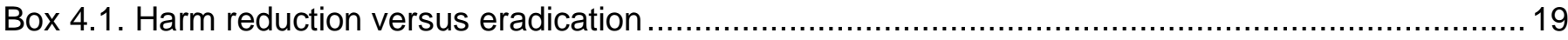

Box 5.1. Supporting existing efforts: an example from Africa................................................... 21 


\section{Introduction}

Transnational organised crime (TOC) has recently developed in ways that place it at the top of the international agenda. Advances in technology and communications as well as in the global political economy have brought about significant changes in the way TOC behaves and operates. TOC is established in many countries around the world irrespective of their levels of development. It is a fluid and diversified industry that engages in a host of illicit activities, including drug trafficking, human trafficking, piracy and counterfeiting. Although it may affect strong states, it is above all conflict-affected or otherwise weakened states that are vulnerable to TOC predations and may serve as bases for international criminal enterprises. The World Bank's World Development Report 2011 expresses great concern about the impact of TOC on economic development (World Bank, 2011).

Global criminal markets pose certain threats to the stability of nation states, even strong states. This is even more evident in fragile or conflict-affected states. Research shows that one of the most important impacts of TOC on a state is the harm it does to the quality of its governance (van Dijk, 2007). The same author states that by corrupting and otherwise compromising the integrity of public officials and institutions through corruption and threat, organised crime erodes the state's long term capacity to provide for the common good. The capacity to deliver public goods is a key element in a state's levels of fragility. A state that is affected by pervasive corruption faces a loss of legitimacy that can endanger its ability to remain in power (Varese, 2000; West, 2006). TOC can infiltrate the structural composition of states, feeding on weaknesses and eventually heightening fragility. Organised crime has thus been established as one cause for state failure, although there is some discussion as to whether TOC is a cause or effect of state fragility and ultimately conflict.

This paper analyses the impact of TOC on conflict and fragility. It focuses on the dynamics of TOC and its relationship to fragile and conflict-affected states, as well as on policy responses and potential entry points for new initiatives that may help tackle this problem. It is organised as follows. In Chapter 2 we define what is meant by transnational organised crime, addressing key developments in how and why TOC has evolved over the last 10 years. We also examine the influences and incentives that encourage the spread of TOC into fragile states. Chapter 3 examines the impact of TOC on conflict and fragility, while Chapter 4 explores policy responses to date using examples from around the world. Chapter 5 seeks to identify possible policy entry points to reduce the impact of TOC on fragile and conflict-affected states. Chapter 6 uses three case studies - El Salvador, Kenya and Tajikistan - to illustrate the main facets and dynamics of TOC in different geo-political contexts. Finally, Chapter 7 offers conclusions and possible areas for new research. 


\section{Key dimensions and developments}

\subsection{Definitions}

\section{Fragile states}

Although definitions vary as to what constitutes fragile states, there is some consensus that they are countries where national and local authorities are incapable of delivering crucial public goods such as safety, security and other basic services, or where their entitlement to do so is contested by rival sources of authority, such as territorial enclaves, ethnic secessions or other armed non-state actors. In both respects, such states are places where the application of global regulatory systems - including prohibition regimes outlawing goods (such as drugs or alcohol) - tend to be weak. Anten et al. (2012) argue that "despite ongoing debate over whether the label of 'fragility' is a valid, appropriate or fair description for these states, the concept of a group of poor countries where the structures of power and authority fail to deliver basic public goods is one that has proved extremely resonant". There are two components to fragility that are recognised in most definitions, namely capacity and legitimacy (Anten et al., 2012). Capacity refers to the state's ability to deliver public goods, services and rights to its population; while legitimacy denotes the state's ability to have its authority fully recognised, accepted and asserted throughout the territory. When a state lacks these, it is said to be fragile. For the purposes of this paper we will work with the INCAF's definition of fragile states, which describes them as having a "weak capacity to carry out basic functions of governing a population and its territory and being unable to develop mutually constructive and reinforcing relations with society" (OECD 2011b:21).

\section{Transnational organised crime}

Defining transnational organised crime is the source of some debate. As Peter Reuter, one of the most recognised experts on the subject, explains (1983: 175): “The term 'organised crime' has never been given satisfactory definition or description. For some, it is a set of relationships; for others, a particular set of activities. The academic and official literatures contain contradictory definitions". Block and Chambilss (1981) establish organised crime as a set of activities (i.e. the provision, transport etc. of illicit goods and services such as protection), as do Hobbs (1988) and others. Others focus their attention on the organisational aspect of the activity by placing emphasis on the logistical and hierarchical structure of criminal groups. These definitional debates stand to this day, and have resulted in a certain ambiguity when referring to TOC. The United Nations High Level Panel on Threats, Challenges and Change admits that "organised crime is increasingly operating through fluid networks rather than more formal hierarchies" (United Nations, General Assembly, 2004: 53), particularly in current global circumstances which we will analyse in further sections of this paper. Most widely-accepted definitions however present two important elements when defining TOC: 1) the sale of illegal goods and services; 2) a certain organised structure with some form of hierarchy that has as its goal the profiting from the above mentioned provision of goods and services; and 3) the perpetuation of their existence through violence (or threat of violence) and corrupt relations with public officials.

In this paper we use a broader definition which seems to incorporate most of the essential characteristics of TOC: "a continuing criminal enterprise that rationally works to profit from illicit activities that are often in great public demand. Its continued existence is based on the use of force, threats, monopoly control and/or the corruption of public officials" (Albanese, 2010: 4). To this must be added an international dimension, meaning the dealings of organised crime must happen through at least two countries. This definition contains nuances. A continuing enterprise may not mean a long-term existence in the same sense as commercial firms or even traditional organised crime structures, like the classic Italian mafias (Gambetta, 1996). TOC may not only be involved exclusively in illicit activities (Paoli, 2002); it has also been known to venture into legitimate businesses such as the service industry and in some cases 
compete for public office, as was the case with Colombia's Pablo Escobar or one of Guatemala's first drug barons, Arnoldo Vargas. Aside from these caveats, the above definition serves the purposes of this paper well.

\subsection{The shifting shapes of TOC: from organisations to networks}

With secrecy being one of the foundations of TOC's survival it is difficult to assess the scope of its diversity and operations; however today we do know much more about TOC than ever before. The sweeping generalisations which are often used to bracket together international crime and fragile states as a leading global "threat" tend to ignore important nuances in the way particular countries and regions have been incorporated into illicit markets. Several different models of organised crime in fragile states can be detected:

1) local organisations primarily concerned with local crime;

2) local organisations with global reach (illicit production);

3) transnational logistical networks; and

4) fragile states as transit points for transnational organised crime.

\section{Local organisations primarily concerned with local crime}

Countries may have thriving organised criminal rackets operating on the more traditional logic of property and market protection in the absence of a functioning state or in connivance with the state. Post-conflict countries such as the Central African Republic (CAR), Burundi and Bosnia-Herzegovina have significant criminal activity with strong state links, but their linkages to transnational illicit markets are of marginal importance, or are sporadic rather than systemic. In the CAR, for instance, illegal exports of diamonds, which represent an estimated 30\% of total exports, are largely conducted by private individuals operating for personal profit (International Crisis Group, 2010).

\section{Local organisations with global reach}

This second model may be regarded as the origin of TOC. This mainly concerns producer nations of illicit or restricted goods which were manufactured in conditions of conflict or territorial fragmentation, and which were then distributed to the global market through commercial intermediaries. Examples are Colombia for cocaine, Angola and Sierra Leone for diamonds. In the case of Colombia in the 1980s distribution was done by home-grown mafia groups with international scope.

Two important dimensions of this second model are worth mentioning. The criminal paradigm within each country was generally based on a vertical structure of power operating in league with parts of the formal state. This model is epitomised by the Angolan military's role in focusing combat operations in resourcerich zones and border areas (Nordstrom, 2007), the warlord politics of Sierra Leone (Reno, 1995) or the centralised network of Escobar's Medellín cartel (Kenney, 2009). At the same time, production of the illicit or semi-licit resource depended on the use of armed insurgent groups that could resist state control over territory, and which came to depend increasingly on these cash-flows for their survival (Cornell, 2007).

\section{Transnational logistical networks}

The model of illicit production has been altered in a number of profoundly important ways since the end of the Cold War. The concerns expressed by the World Bank's World Development Report 2011 (World Bank, 2011) or the United Nations Office on Drugs and Crime's report on transnational crime (UNODC, 2010) now centre on the intermediary roles played by a growing number of post-conflict or fragile states in the global distribution of illicit goods. ".i These countries are primarily the Central Asian republics (opiates 
from Afghanistan); in Central America and the Caribbean (narcotics and human trafficking from South America, while arms move south from the United States); and in West Africa (cocaine and migrants to Europe, as well as financial scams and "blood diamonds"). In all cases, the largest revenues $-85 \%$ of the total value of transnational crime, according to the UNODC (UNODC, 2010) - appear to derive from the trade in drugs.

Drug trafficking is one of the most profitable illicit businesses in the world today. The cocaine market in Western Europe and the United States alone has been calculated to be worth USD70 billion annually (UNODC, 2011). The global drug market was estimated by the United Nations at about USD 400 billion as far back as 1997 (UNDCP, 1997). Despite debate about the veracity and usefulness of these estimates (Reuter and Greenfield, 2001), clearly this illegal market is profitable and attractive for many criminal elements. The drug trade is by definition international. Countries produce, transport and consume narcotics. Fragile states are key elements in the movement and production of drugs since they can offer safe haven for TOC. At the very least, they present a lesser risk to the operations of TOC than strong states.ii

It seems that the key factor that determines the success of an illicit supply chain is not so much the production of the goods themselves as the logistical skills involved in their transport and delivery. Informal power in these illicit markets, notably those for heroin and cocaine, has correspondingly moved along the supply chain from production to logistics; from "traditional" mafia that control production and exerted a certain authority over society to criminal groups or networks in charge of the principal market gateways such as Turkish mafia for heroin and Mexican cartels for cocaine (Box 2.1) - or to mafia with expertise in co-ordinating logistical networks across various countries, such as Nigerian traffickers (Ellis, 2009). The logistical skills of these networks in turn leads to their involvement or association in numerous other criminal markets - such as human trafficking, Internet fraud, piracy, counterfeit goods and arms trafficking.

\section{Box 2.1 The spreading tentacles of TOC: the Mexican Zetas}

The Zetas in Mexico are a perfect example of the opportunism that makes TOC fluid. They have diversified their criminal activities from the distribution of cocaine to the US to the production of methamphetamines, human trafficking and other illicit activities such as extortion and racketeering; the same group has also set up bases in Guatemala and other Central American countries, where it has been associated with a number of acts of extreme violence. This territorial expansion is in part a result of the Mexican government's repressive drug policy and militarisation of the war on drugs, which has increased the costs of the cocaine trade for those involved in its distribution. The same gang is known to have contacts in the Caribbean, where it exploits local states' weaknesses to extend cocaine and heroin distribution to Western Europe and the United States (Gastrow, 2011). At the same time, a number of recent violent incidents suggest the group is undergoing a major schism. It is important to note however that this mobility is still rare as mafias tend to be stationary, while forming links to other groups (Morselli et al., 2010, Varese 2011).

In many cases control of international criminal trade is no longer left to one or two larger criminal organisations. Today, smaller more reactive networks operate. In the Kenyan case, it is estimated that around ten groups account for the management of most of the drug trade there. These groups contain up to 20 members with strong connections to the political elite (Gastrow, 2011). Meanwhile, an estimated 268 gangs, with varying levels of connection to TOC, operate in Jamaica (Leslie, 2010).

The shift of emphasis in TOC from production to logistics that has taken place over the last 10 years has meant significant changes in the way TOC is structured. Previously the main modus operandi was through long-standing hierarchical and patrician organisations operating in a manner similar to legitimate 
transnational firms. The Sicilian mafia, the Japanese yakuza or Nigerian groups which co-ordinate heroin trafficking to the United States are examples, usually based around kinship networks or a shared ethnic background (Albanese, 2010). While these groups still exist, their form of operation and reach has changed. There is growing evidence that organised crime groups are more constrained by structural limitations such as local settings, and actual criminal markets than previously thought (Morselli et al., 2010). At the same time, there is growing evidence that TOC activity has moved away from a system of hierarchical, strategic, turf-based groups into interconnected, flexible and opportunistic networks, driven by a changing global context. TOC may move into new areas of action, leave old ones or enter different criminal enterprises depending on a series of political-economic and structural factors. In the words of UNODC, "organised crime seems to be less a matter of a group of individuals who are involved in a range of illicit activities, and more a matter of a group of illicit activities in which some individuals and groups are presently involved" (UNODC, 2010: 29). This goes against the general view that sees TOC in terms of highly mobile, strategic organisations.

\section{The rise of transit states}

A key element of the logistical operations of TOC is the exploitation of fragile states as transit points in a supply chain. In other words, TOC penetration of the state may have nothing to do with the local market whether in terms of production or consumption - and much to do with securing the passage of illicit goods to another country. A notable feature of TOC operations in this model is how the transnational criminal market may be relatively insulated from the surrounding social context; drug consumption in Central America is low compared to the rest of the hemisphere, for example (UNODC, 2011b).

States caught up in this form of TOC can be described as victims of circumstance, in that the final user market could be equally well served through alternative routes; it has been observed in the case of Mexico, for instance, that "the United States is central to Mexico's drug problem, whereas Mexico is incidental to that of the United States" (Kleiman, 2011). But however "incidental", the emergence of network-based TOC in countries of passage is extremely corrosive of social trust and public institutions, and supportive of new criminal ventures.

However, it is also clear that transnational crime depends crucially on the co-operation of local officials and security forces, and on the consent or indifference of the public. The study of different cases suggests that the arrival of TOC in a fragile state is rarely, if ever, a hostile takeover or a matter of foreign cartels intimidating and corrupting local authorities (plomo o plata, to use the Spanish expression). Criminal cartels are more usually invited, either by local crime bosses - as seems to have occurred with the Zetas in Guatemala - or by insurgent groups looking for a new source of funding, such as the Islamic Movement of Uzbekistan (IMU). There is evidence that the inception of politico-criminal alliances in Colombia owes much to the initiative of local political elites (López, 2010). The intermediation provided by Nigerian traffickers in the establishment of a Colombian drug trafficking route though Guinea-Bissau also points to political and military complicity (Ellis, 2009).

\subsection{Why does TOC spread into fragile and post-conflict states}

Recent analyses of TOC mobility have also stressed a number of "push" and "pull" factors that determine the spread of criminal enterprises into new contexts, while placing overriding emphasis on the influence of "pull"; above all, the opportunities of new unregulated markets, the absence of a functioning state or an existing criminal presence in the market (Morselli et al., 2010; Varese, 2011). Some of these factors are explored further here.

\section{Global criminal expansion}

Opportunities provided by the infrastructure of the global economy have been appropriated by transnational crime to service high and rising demand for illicit goods. The flexibility and speed of 
commerce, the diversification of trading routes and the ease of electronic communication pose huge obstacles to efforts to strengthen border security and control criminal activity. Innovations such as the shipping container, or the rise of international cash transfer firms, have played crucial roles in assisting the growth of a global illicit economy (Levinson, 2006). Where measures might conceivably be taken to deter cross-border trafficking - such as by systematic scanning of shipping containers, or by rigorous inspections at borders and customs posts - they are confronted with capacity and resource limitations in security forces, as well as by the economic imperative of maintaining trade flows, especially for perishable goods. This issue is acute in the case of transnational shipping: international ports, which have become the means of entry for all sorts of illicit goods alongside legal ones, are acutely fearful that slower processing of containers through more rigorous inspections will force business elsewhere (Nordstrom, 2007). Even when controls are imposed, they may still be circumvented by the targeted corruption of key officials.

\section{Institutional fragmentation}

The socio-political fragmentation that is often typical of many fragile states (Migdal, 2001) provides opportunities for TOC to establish partners in these environments, as well as giving interest groups and power-holders within the country strong motives to seek out opportunities for collusion with TOC. A number of characteristics of fragile states stand out for the way in which they help to generate these mutually reinforcing incentives that bring TOC and local power-holders together. ${ }^{\text {iv }}$

High levels of institutional fragmentation, particularly in the security forces and between the central and local levels of the state, enable isolated pockets of officials to establish stable relationships with organised crime without suffering close monitoring or regular control. At the same time, by corrupting poorly coordinated state and security institutions, TOC can unlock particular services or deactivate security controls without having to engage in costly system-wide bribery. The transition to competitive electoral democracy in Central America, the introduction of devolved municipal powers in Colombia, and the political rivalry of elite and clans in post-Soviet Central Asian Republics such as Tajikistan and Kyrgyzstan (Engvall, 2006) have all resulted in atomised state structures, in which officials, politicians and other power-holders vie for access to the additional resources provided by criminal activity. In so doing these actors strengthen their patronage power and thereby consolidate the support of their local clients.

\section{Social fragmentation}

The specific regions in which TOC flourishes tend to be marked by weak interpersonal ties and social capital. While kinship or ethnic groups in these areas may enjoy very strong internal bonds of trust and support - which may be reinforced by the absence of state authorities or by economic hardship - the ties between separate groups tend to be markedly weaker. The reasons for this are varied. Frontier status, the recent creation of population centres, dependence on migrant labour and economic distress can mean that bridging social capital - the interpersonal bonds linking people from different social groups or ethnicities - is in short supply (Putnam, 2000). As a result, community control and oversight over the behaviour of security forces, state officials and other citizens are weak. These characteristics can be found in areas such as the Petén region of Guatemala (first exploited with state backing in the 1960s, and then largely abandoned by central government); the maquila-dependent frontier towns of northern Mexico (particularly Ciudad Juárez); or some of the principal nodes of drug trafficking in Central Asia, such as the Kyrgyz city of Osh, which erupted in politically-manipulated ethnic violence in 2010 (Reeves, 2010).

Relations based on kinship or a shared ethnic background have long been found to play an important role in the creation of criminal organisations, in large part due to the ways they provide bonds of trust and a shared language. The case of wartime Kosovo in the late 1990s stands out for the way that the guerrilla Kosovo Liberation Army drew on support in the diaspora and among ethnic Albanian Kosovars, while also earning money through deep involvement in the European heroin trade and human trafficking (Strazzari, 
2008). Across the multiple Central Asian borders relatively small consignments of heroin tend also to be handled by groups that are based on clan membership or shared ethnic ties (UNODC, 2010; Paoli et al., 2007).

\section{Inequality and a poorly-functioning state}

Another source of mutual reinforcing incentives is the way transnational criminal enterprises latch onto the existing social and economic inequalities in a fragile context in order to sub-contract tasks, and build support networks for their activities.

For example, extreme socio-economic inequalities in Central America have been exploited to establish broad communal consent to the activities of organised crime. One recent field-based study of the Atlantic coastal region of Nicaragua found public sentiment to be highly tolerant towards drug trafficking in the absence of other economic activities (Quiñónez et al., 2010). In all these cases, TOC may gain public legitimacy and popular support by acting as a substitute state, providing employment and basic public goods such as protection.

\section{Criminal legitimacy?}

The emergence of heavily criminalised environments, in which TOC groups enjoy stable and even overt relations with public authorities, raises the question of the extent to which criminal actors can be regarded as popular or publicly-accepted organisations. In other words, to what extent have these organisations managed to establish a new sort of social contract with local populations?

A number of aspects of this complex issue can be identified. It has been said that TOC can, and indeed does have a positive impact on some of the communities in which it finds itself (Skaperdas, 2001). ${ }^{\vee}$ In situations of economic and social hardship, as are often found in fragile states, TOC may offer the only means of survival and thus acquire legitimacy or social embeddedness (Manrique, 2006; Adams, 2011). This may be especially the case in remote rural areas or very marginalised urban ones where there is scant government presence. Poor rural areas where illegal crops or commodities are among the few profit-making alternatives available to farmers and workers may tend to support criminal activity, or local armed actors operating in TOC. Trafficking can also play a similar role as a coping mechanism. For example, in Tajikistan heroin smuggling became an important means of survival for families affected by the civil war of 1992 to 1997 (see case study in Chapter 6). In Central America in the 1990s post-conflict demobilised youth formed self-protection units that provided communities with organisation and protection (Rodgers et al., 2009). In more developed urban economies, the capacity of criminal organisations to control levels of crime in their area as if turning a tap on and off gives these groups appeal in areas blighted by violence. The most recent example is the agreement in March 2012 between representatives of the government of El Salvador and mara leaders to halt the country's wave of homicides (see the case study in Chapter 6). ${ }^{\text {vi }}$

However, these cases provide limited or questionable evidence for the existence of any strong public support for or even acceptance of organised crime. The hallmark of almost all exceptionally criminalised urban environments - such as Medellín in Colombia, or Ciudad Juárez in Mexico - has been the absence of state authorities and services, or the corrupt and patronage-based behaviour of public bodies. Criminal organisations in most cases offer an inferior substitute to the state. There is evidence gathered over time in Central America (Rodgers et al., 2009) which suggests that TOC "legitimacy" - along with misguided, violent attempts by the state to deal with it - instead ends up with the further erosion of the community's social fabric, the corruption and consequent further de-legitimation of state actors, and higher levels of violence. Moreover, the community protection supposedly offered by gangs and criminal groups also allows for predation of resources as well as outbreaks of factional violence, and is insensitive to the requirements of sustainable development. For example, the neglect of public buildings and theft of state resources in areas of Colombia affected by heavy paramilitary and criminal presence has been striking 
(Torres, 2010). Over time, the rise of more violent and larger criminal organisations that are more attuned to profit-making can undermine the association between illicit activity and defence of the community's interests (Rocha, 2006).

It could thus be argued that the potential short-term benefits of TOC presence are soon cancelled out by the long-term, structural damage these groups inflict on the communities that house them. It is important to make a distinction between informal systems of governance (Dixit, 2004) - which may be non-state sponsored and common to many countries (such as clan structures in some parts of Africa) - and TOC control of a region. This distinction is fundamental in that these two forms of control are based on different mechanisms. TOC may impose a corrupt form of legitimacy through fear and intimidation (which puts into question whether they are actually legitimate), while other forms of non-state governance may be fully legitimate and freely accepted by those in their sphere of influence.

\section{The entrenchment of crime}

The factors mentioned above serve to strengthen the overlapping interests of transnational crime and nationally-based groups and power-holders in fragile states. In fact it is extremely hard to isolate the effects of the domestic political economy from more diffuse global influences. A country's institutional weakness and fragmentation, socio-economic inequalities, uneven regional development and openness to corruption can all encourage TOC groups to operate and local elites to provide opportunities for these criminal entrants. At the same time, local criminal groups are also influenced by a set of dynamic global processes which mould their conceptions of material gain and ethical behaviour. These second-order processes include patterns of migration, the global spread of electoral competition, decentralised state structures, limited state intervention in the economy, the establishment of regional economies oriented to commodity export or manufacturing assembly, as well as the broader cultural influences of materialistic aspiration. These are not intentionally linked to the spread of TOC, but would appear to play an important role in enabling partnerships between international and local groups. For example, the spread of drug trafficking in Central Asia would have been inconceivable without the end of the Cold War, the concomitant decline of state-planned economies in favour of poorly-regulated capitalism, and the rise of clan and elite-dominated polities.

However, once it is entrenched in a country or region, criminal enterprise has its own dynamic that is particular to the area, and whose development is to a large extent endogenous. The establishment of a general public tolerance of illicit behavior and armed violence, the formation of a close nexus between political and criminal elites and the generation of new forms of criminal activity are all phenomena that are now visible in states affected by transnational crime - even where the influence of global trafficking networks appears to be on the wane (Box 2.2). 


\section{Box 2.2. The entrenchment of violence as a way of life}

Both Jamaica and Colombia have seen their role as a strategic hub for transnational crime diminish in recent years: Mexican cartels have displaced Colombians in control of the trafficking routes to North American since the 1990s; ${ }^{\text {vii }}$ while Jamaica, and the Caribbean in general, have seen declining cocaine seizures over the past 15 years. At the same time, criminal control over urban territories in Jamaica (known as "garrison communities") and the island's murder rates have reached historic highs in this period of diminishing relevance to TOC. Heavy paramilitary involvement in local and national Colombian politics, meanwhile, can be dated from 2002 - long after the demise of the great national drug cartels and their substitution in the global supply chain by Mexican cartels (López, 2010). In both of these countries, furthermore, numerous studies point to the entrenchment of violence as an accepted method for solving personal problems, or for governing and defending communities. A survey in the Colombian city of Medellín in 2010 revealed that 38\% of residents approved the use of violence to eliminate someone who poses a threat to the community (Adams, 2011), while a national crime victimisation survey in Jamaica in 2006 found that $43 \%$ of those living in garrisons claimed that local criminal bosses, known as "dons", had done positive things for their communities (Leslie, 2010). One recent estimate suggests that $60 \%$ of all urban constituencies in Jamaica have been turned into such garrisons, in which dons offer the principal means of access to public services and employment opportunities, both licit and illicit (Harriott, 2007).

Ever closer cohabitation of criminal and political elites has been witnessed in various contexts, notably in certain regions of Colombia, municipalities of Mexico and Guatemala and in Central Asia. This results in an advanced form of state capture, meaning control of governance by criminal groups, that may give a dominant role to a new "hybrid" elite of criminalised politicians (Garay-Salamanca et al., 2010). Attempts to roll back this influence through state-led recapture of urban areas may, if poorly co-ordinated, deepen local populations' dependence on criminal actors (Felbab-Brown, 2011).

Entrenchment of a violent culture of organised criminality tends to drive the emergence of new illicit practices, such as protection rackets, capture of public sector resources, seizures of property and land, and eventual entry into the licit private sector. Although the levels of violence practised by the classic hierarchical mafia - as in Italy and Russia - have begun to decline, the shift from transnational trafficking towards local protection and state co-option seems to have accentuated levels of violence in a number of cases, such as Mexico, Guatemala and Jamaica (Olson, 2012). At the same time, tolerance of ever higher rates of violence, support for extra-legal responses by the authorities or vigilantes, and dependence on private security are common public responses (Adams, 2011). The emergence of such violent criminal environments has led some commentators to express concern over the possible rise of cartels and gangs seeking more systematic control over political bodies and territorial enclaves (Bunker and Sullivan, 2011). 


\section{Impacts of TOC on conflict and fragility}

While TOC is generally associated with fragile and conflict-affected states, there is some debate over whether it is primarily a cause or an effect of fragility and internal conflict. West (2006: 11) argues that even though the presence of TOC can be "a symptom of state weakness it has created its own dynamics that intensify the causes of state failure and is itself best conceptualised as a proximate cause". Afghanistan is an example of this. Poppy growing and the subsequent heroin trade are symptomatic of the fundamental weaknesses of the Afghan state. They have also been found to be key elements in defeating the state's efforts to establish a strong rule of law throughout the country. The drug trade there provides funds "...for non-state actors [local warlords in this case] to challenge the state and maintain an enduring violence..." (West, 2006: 3).

Van Dijk (2007) argues that one of the most important impacts of TOC on a state is the harm it does to the quality of its governance. By compromising the integrity of public officials and institutions through corruption and intimidation, TOC undermines the state in the two key areas of capacity and legitimacy: 1 ) the state's capacity to deliver basic public goods and citizenship rights; and 2) its legitimacy as the political entity in charge of government (Varese, 2000; West, 2006). This has important implications for peace processes in that it subtracts from the legitimacy of the actors involved, as well as that of the process itself.

The risk that TOC presents for fragile states has been recognised by international organisations. The United Nations High Level Panel on Threats, Challenges and Change stated as far back as 2004 that "Transnational organised crime is a menace to States and societies, eroding human security and the fundamental obligation of States to provide for law and order" (United Nations, General Assembly, 2004: 52). The same document also points out the need to tackle this issue with special regard to post-conflict situations where former combatants may seek to "exploit criminal connections...undermining peace building efforts" (United Nations, General Assembly, 2004: 53). The risk from criminalised elements in post-conflict scenarios is such that it may act as a peace spoiler, undermining the possibility of successful peacekeeping operations (Cockayne and Pfister, 2008). These three main impacts of TOC on fragile states are explored in more detail below.

\subsection{Eroding the state's capacity to deliver public goods}

TOC thrives in areas of low or non-existent formal state control. These are contexts of low contract enforceability, lax border controls, and poor provision of public goods. Note that this does not necessarily mean that the state is absent, but may rather suggest that the state is behaving in such a way as to favour the emergence and arrival of TOC. The traditional view that sees TOC and the state as competing entities fails to take into account the complex relationships between these two actors and the civil society in which they are nested (Arias, 2006). In fragile and conflict-afflicted states TOC can harm the state's capacity to deliver much-needed public goods such as safety, health and sustenance. Pre-existing fragility means that to begin with the state is unable to deliver these goods. TOC will see this as an opportunity to establish itself in such a market and set up its informal networks there. It also has a tendency to infiltrate formal institutions as well as the legitimate economy through corruption of its agents (van Dijk, 2007). This infiltration has been referred to as a form of cronyism (Kaufman, 2003: Kaufman and Kraay, 2002) that ultimately undermines the possibility of economic development. This is because the climate of uncertainty that TOC creates makes investment and even aid very difficult (van Dijk, 2007). By further weakening already debilitated states TOC impairs public goods provision and ultimately undermines development and good governance. 


\subsection{Harming the state's legitimacy}

A state's legitimacy is clearly linked to its economic and social development: if one fails the others follow in a downward spiral. TOC is often a prime catalyst in this process. As we have exposed in the paragraphs above, TOC exploits weakened states to establish criminal markets and enterprises. This process is usually characterised by systematic and pervasive corruption and cronyism. By appearing to be captured or favouring criminal networks a state can fall irretrievably into a legitimacy crisis (Varese, 2000) by which the general population loses trust in the state's capacity or willingness to provide for their wellbeing. Loss of legitimacy results in a weak and unsupported state structure that may fall further into conflict and fragility, further degrading the capacity of the state to provide basic public goods. TOC may also provoke other issues of legitimacy that can impair a successful peace and statebuilding process; if a state's control of the use of violence and force over a territory is undermined by TOC the role of the state as the sole protector of the population is undermined (Tilly, 1985).

\section{3. $\quad$ Affecting peace processes}

TOC in fragile and conflict-afflicted states may have been born out of conflict itself - as gun trafficking networks for example; it then remains after the conflict and engages in other illegal activities. Alternatively, TOC may have been there before the conflict and survived through it. In any case, criminal groups are a challenge to peace processes and disarmament, demobilisation and reintegration (DDR) through corruption or through their links to the political establishment (Ashdown, 2006). Other forms of crime also flourish in post-conflict scenarios; studies show that in some African countries many crimes increase in the aftermath of conflict, including armed robbery, child prostitution and drug dealing (Baker, 2009). The rise of urban crime in Central America has a similar dynamic and presents an important policy challenge.

Criminalised elements in post-conflict scenarios may undermine the possibility of successful peacekeeping operations (Cockayne and Pfister, 2008). Thus the management of organised crime is a central element - albeit not always formally recognised - of many peacekeeping interventions. It is no secret that in many cases peace missions have had to engage directly with TOC in order to be able to operate (Cockayne and Pfister, 2008; Cockayne and Lupel, 2011). 


\section{NOTES}

'Some authors have questioned this (e.g. Reuter, 1983; Paoli, 2002), suggesting instead that the provision of illegal goods and services is not particularly organised and that their structure is not always hierarchical and wellestablished, for example the Cosa Nostra in Italy.

ii There is now less concern about the incorporation of more producer nations into international illicit markets - if anything, illicit production of the coca leaf and the opium poppy has become more geographically concentrated rather than dispersed over the past 20 years. The same cannot be said, however, for the production of marijuana or synthetic drugs (see UNODC, 2011).

iii It is important to note that TOC does not always settle or arise in fragile or conflict states. Mexico is a good case in point. It is a country with a solid and growing economy (one of the 15 largest in the world), free and fair elections and a strong government with no risk of collapsing, and yet it has developed a strong TOC presence for other structural and geo-political reasons - including a weak rule of law and closeness to a large drug market.

iv See also Briscoe (2011).

${ }^{\vee}$ Skaperdas does not, however, argue for positive effects of TOC. He merely states the services they provide and likens them to a primitive form of the state.

${ }^{v i}$ Reports from the El Faro website have claimed that this deal involved moving a number of mara leaders away from high security holding facilities. On April 14, 2012, a few weeks after this pact was reported, El Salvador witnessed its first day without any homicides in three years.

vii Although Colombia remains the world's principal producer of cocaine, its criminal organisations are held largely responsible for trafficking to Europe. 


\section{Policy responses to date}

Many actors are involved at all levels in initiatives to tackle TOC in fragile states. International organisations such as the United Nations are actively involved with national governments in designing and sometimes funding programmes, while local actors such as municipal or provincial-state governments are responsible for implementing them.

In recent times there has been an important shift in the way the international community deals with TOC. Traditionally viewed through a narrow lens of crime and its causes, TOC was (and still is in many instances) dealt with as a legal or security issue. That is to say it has generally been tackled with repressive measures and a focus on the market aspect, particularly supply. Today we see a growing number of proponents of a more complete approach to TOC, set within the political economy context of the problem. This approach applies to:

- statebuilding: "an endogenous process to enhance capacity, institutions and legitimacy of the state driven by state society relations" (OECD, 2011b: 20);

- peacebuilding: "a range of measures aimed at reducing the risk of lapsing or relapsing into conflict, by strengthening national capacities for conflict management and laying the foundations for sustainable peace." (UNDPKO, 2008: 18); and

- the war on drugs

While much work remains to be done, and the international community is in a perpetual race to keep up with changes in the political economy of TOC, the learning process of the last 25 years is resulting in many interesting debates that seek to reform the way statebuilding and peacebuilding endeavours are designed, and the way the trade in narcotics is tackled.

\section{1. $\quad$ A more comprehensive approach to statebuilding by development agencies}

There is evidence that simply increasing a country's income (through investment or aid) does not, on its own, necessarily lead to improvements in governance (Kaufman and Kraay, 2002). This is because such policy responses must not only strive to increase economic wellbeing, they must also be accompanied by investment in social inclusion and in fostering resilience at all levels. This has been stressed by a number of organisations such as UNODC, the United Nations Development Program (UNDP) and other international actors.

UNODC has a clear mandate to tackle TOC (UNODC, 2008). It operates a number of protocols such as the United Nations Convention against Transnational Organised Crime, as well as the United Nations Convention against Corruption. The focus has been on capacity building in direct relationship with states. The UNDP has devised an Immediate Crisis Response Programme to enable the agency to respond to crises promptly. In one of its most recent publications the UNDP also recognises the need to address TOC in fragile and post-crisis states (UNDP, 2012). This necessarily includes heavy investment in governance but in a way that recognises the endogeneity and the inherent complexity of the statebuilding process. The OECD's Development Assistance Committee (DAC) has recognised the need to address development and statebuilding in fragile states as a function of local contexts and international dynamics (OECD, 2011b). This would have a direct impact on the dynamics of TOC.

Investment in governance should indeed be a policy priority for agencies. Investment in this area has been substantial: "in 2009, for example, at least USD33 billion was invested globally by major bilateral donors in these settings, including for governance-related projects" (UNDP, 2012). Thus there is no lack of 
resources to tackle this issue. But while broad governance issues are key to tackling TOC, international agencies such as UNDP - perhaps by force of their size and clear international focus - do not get involved in the micro-level needs of fragile countries and the communities that compose them, such as protection from everyday forms of violence. Such agencies are also somewhat beholden to the agendas of their member states, which at times do not coincide with UN mandates or indeed with the specific needs of fragile states on the ground. This has sometimes resulted in resources being used inefficiently and a lack of connectivity between agencies and local governments. Often local (municipal and state) governments are left out of the decision-making process. The question that arises is how to reconcile international mandates with local needs (ICPC, forthcoming)? Section 5.3 discusses some possible answers to this question.

While agencies such as UNODC and UNDP have a wealth of experience and a clear mandate they sometimes lack a consolidated strategic approach. For example Muggah (2009) argues that it is imperative for the success of peace processes (or any statebuilding effort) to integrate a holistic approach in peace interventions which include conflict prevention and which construct the basis of a working legal system from the ground up. A bottom-up approach will help to take into account all actors involved in policy-making processes.

\section{2. $\quad$ A more integrated approach to peacekeeping missions}

As we have seen, TOC can establish itself after the end of a conflict by exploiting power vacuums and weak regulation. However, there is some debate as to whether conflict and post-conflict situations tend to intensify the occurrence of TOC or not. The weakening of state institutions during conflict as well as the normalisation of violence may make TOC more likely to appear (Adams, 2011). On the other hand, all-out conflict may prove to be a disincentive for TOC as fighting makes it more and more difficult to operate. This may actually make the presence of peacekeeping forces a "structuring" factor that may provide TOC with the minimum stability it needs to operate (Cockayne and Pfister, 2008). In any case peace operatives have to deal with TOC actors to be able to carry out their tasks properly. While there may be some "positive" effects of TOC during and after conflict - such as TOC's ability to smuggle basic goods to populations which have no access to aid - these are very marginal and should not undermine the notion that TOC has negative effects on the peace and statebuilding process in the long run.

Traditionally peacekeeping missions have addressed TOC (and local organised crime) through a confrontational strategy based on the application of the law. There has recently been a drive to change this. The International Peace Institute held an important international forum in 2007 that pushed for a more "holistic, integrated approach" (Cockayne and Pfister, 2008). This approach looks at the structural and sociopolitical characteristics of TOC at the local level so as to tailor the international response to each conflict. Accepting that TOC is often structurally nested in conflict zones (such as poppy growing and heroin production in Afghanistan) will allow peace operations to focus on a more "managerial" strategy for dealing with TOC (Cockayne and Pfister, 2008). This would allow for effective statebuilding with minimal violence and also would avoid confusing the needs of short-term peacekeeping - which includes the pragmatic establishment of minimum security for peace - with long-term governance issues. This requires new thinking on three fronts:

1) International co-operation that allows peacekeeping forces to access information and intelligence on TOC; this includes the creation of new guidelines from international organisations on peacekeeping.

2) Working with local populations to establish the roles and limitations that peace forces can have regarding TOC on the ground.

3) Generating necessary data and frameworks to fully understand how TOC works in conflict areas. This last point demands cross-disciplinarian expertise and methodologies. The connection of TOC with economic development must also be addressed. Legitimate sources of income have been found to be 
lacking in areas of former conflict, which feeds into TOC dynamics.

\section{3. $\quad$ Moving beyond the war on drugs}

Traditional means of tackling the drug trade have been through repressive eradication strategies - as in Colombia and Afghanistan where both production and trafficking were tackled by military means. These methods have had mixed results. In Colombia violence decreased in the aftermath of Plan Colombia, ${ }^{1}$ but is now on the rise again. The small decrease achieved in cocaine production merely meant increased production in other Andean countries, with the result that total production has remained mostly constant (UNODC, 2011). In Afghanistan poppy eradication measures have backfired as local producers see their only livelihood disappear, eroding support for Western intervention. In Mexico, direct militarised confrontation of drug cartels has resulted in the death of close to 50000 people in the last six years, yet cocaine trafficking remains a challenge. The only result has been an increase in incarceration rates - the total prison population of Mexico increased by over 45\% between 2000 and 2011 (INEGI, 2011). ${ }^{2}$ Today many actors are challenging the war on drugs approach.

In 2009 a consortium of high-level politicians and intellectuals (headed by former president of Colombia Cesar Gaviria, former president of Mexico Ernesto Zedillo and former Brazilian president Fernando Henrique Cardoso) created the Latin American Initiative on Drugs and Democracy. This organisation sought to re-evaluate and reframe the war on drugs given its lack of results. The initiative pushes for an open debate on the decriminalisation of certain soft drugs such as cannabis. It is critical of prohibitionist policies and eradication programmes that seek to eliminate the totality of the drug trade and claims that the pursuit of this policy has generated more violence while having little effect on patterns of consumption. The initiative also claims that the drug trade has undermined the power of many states and threatens to corrupt many others. It also argues that the illicit drug trade fuels other forms of criminal activity such as armed violence, gun trafficking and overall violence among gangs and between the gangs and the state. Along with a policy of decriminalisation, the initiative advocates the implementation of harm reduction policies (Box 4.1) as a more humane way to tackle the drug issue (ICPC, forthcoming). New approaches that focus on harm reduction as opposed to total eradication have shown good results (ICPC, forthcoming). For example, the Australian government has successfully implemented a drug policy that makes harm reduction a central tenet and has reported important advances in tackling drug abuse and drug related social harm (ICPC, forthcoming).

\footnotetext{
${ }^{1}$ Plan Colombia was a USD 7.5 billion strategy to fight drug production and TOC in Colombia. It was funded in part by the Colombian government and received close to USD 1.6 billion from the United States and the rest from the international community.

${ }^{2}$ More research is needed to fully establish this relationship; however this important increase coincided with the country's war on drugs.
} 


\section{Box 4.1. Harm reduction versus eradication}

Harm reduction policies acknowledge that the drug trade can not be fully eliminated (the ultimate goal of traditional eradication programmes); instead they focus on reducing the harm that it causes to society in general. Some of its policies include: tackling drugs as a public health problem as opposed to a criminal one, by decriminalising users and making help available to them; minimising the effect of drugs by strengthening the capabilities of communities; using preventive strategies by tackling demand; and reinforcing supply control.

A good example of a successful harm reduction approach is the Australian National Drug Strategy (NDS). Since the 1980s and through a number of iterations the NDS has integrated harm reduction and community strengthening principles to already existing supply control strategies to great success.

For more information go to www.nationaldrugstrategy.gov.au/.

Recently these ideas have been further developed and given added relevance through the Global Commission on Drug Policy. This initiative is now spearheaded by active heads of state - notably Guatemala's President Otto Perez Molina, who has voiced a deep commitment to decriminalisation and an end to the current war on drugs. This will have direct implications for international organisations such as the United Nations who must respond to the needs of their active members.

The commission openly asks states to experiment with "models of legal regulation of drugs to undermine the power of organised crime..." to "...end the criminalization, marginalization and stigmatization of people who use drugs but who do no harm to others....", to "....invest in activities that can both prevent young people from taking drugs in the first place and also prevent those who do use drugs from developing more serious problems...", to "... offer health and treatment services to those in need..." and to focus law enforcement efforts "...not on reducing drug markets per se but rather on reducing their harms to individuals, communities and national security". In short it aims to "begin the transformation of the global drug prohibition regime. Replace drug policies and strategies driven by ideology and political convenience with fiscally responsible policies and strategies grounded in science, health, security and human rights and adopt appropriate criteria for their evaluation" (GCDP, 2011). If successful, this initiative will have a massive impact on drug policies and how they are understood and implemented. While law enforcement is still today the most common response to drug markets, this recent shift signals perhaps the beginning of the end of repressive drug policies towards a system that prioritises health and harm minimisation. This, of course, will take time. Traditional forms of enforcement are deeply engrained in the international system and to expect a quick change from this to a more humanistic and harm minimising approach is unrealistic. However the mere fact that these issues are being discussed at such high levels bodes well for the future. 


\section{Entry points to tackle transnational organised crime}

A re-assessment of the policies by which TOC has been tackled is now in order. As we have seen TOC is part of a web of cause and effect, which means that it cannot be effectively dealt with in isolation. As far as possible various connected issues on both a macro and a micro level must be included in policies to mitigate the effects of TOC on fragile and conflict-afflicted states. Here we focus on five key areas:

1) Co-operation and shared responsibility along the supply chain

2) Concurrent macro and micro level development

3) Combined top-down/bottom-up approach to development

4) Better training and research to support peace operations

5) Standardising definitions and information across the supply chain

It is important to note that all entry strategies need to be based on local realities, on a firm commitment to human rights and on solid empirical evidence.

\subsection{Co-operation and shared responsibility along the supply chain}

This is one of the most important dimensions for addressing TOC. As we know, TOC is a global enterprise, spanning many countries in all continents and for a myriad of illicit markets. TOC is partly a response to a demand for illegal products and services. The developed countries that receive and consume illegal goods need to address their side of the problem as much as producer and intermediary countries are expected to deal with theirs. While it is imperative to deal with the supply side of the equation, as long as there is a demand TOC will continue to supply illegal goods and services. Coordination is therefore needed around the type of TOC trade to be tackled (drugs, piracy etc.) and should involve co-operation among both national and international actors and agencies during structural reforms aimed at statebuilding. It should include the sharing of intelligence on TOC, the design and implementation of aid packages and peace missions, as well as complementary legislation throughout the countries involved in the trade. A multi-pronged approach that tackles all stages of the supply chain concurrently, from production to end-user, is desirable.

\section{2. $\quad$ Simultaneous macro and micro development}

Fragile and conflict-afflicted states are usually characterised by a weak rule of law. TOC fills vacuums in regulation and enforcement and, as we have seen, undermines the legitimacy of the state. This is why building democratic ${ }^{1}$ and law-abiding institutions and the establishment of a strong rule of law are key aspects of statebuilding. The challenge in this area is to balance the need for immediate security and safety, which may involve compromise with TOC, with the long-term needs of a functional state. The international community has much to offer in this respect with targeted technical aid during statebuilding processes (Box 5.1).

A country is only as strong as its weakest communities and these are determined by the quality of its governance. Macro-level institution building must occur alongside the micro development of local communities. This includes education, community safety, work and health as the basic building blocks of resilience. Fragile states are rarely able to fully provide these most basic public goods, which gives TOC a window of opportunity to establish itself and prey on local communities. Ensuring the availability of basic public goods as well as tackling the social embeddedness of violence, discrimination and other social disadvantages will make communities better able to resist TOC inflitration. Institution building and peacebuilding are thus different elements of the same concurrent, multi-level process.

\footnotetext{
${ }^{1}$ A debate exists as to whether democracy itself can guarantee peace. And its direct correlation has been contested (see for example: Inglehart and Welzel, 2009; Ohlson and Söderberg Kovacs, 2009).
} 


\section{Box 5.1. Supporting existing efforts: an example from Africa}

It is important to recognise that local and national governments are often acting to tackle TOC in their jurisdictions. These local countervailing forces - such as anti-corruption agencies and other government bodies - have a crucial role to play in facing TOC. In Nigeria the Economic and Financial Crimes Commission is poised to play an important part in tackling the financial aspects of TOC with a new and more competent leadership. These efforts must be supported by the international community as a way of generating institutional capacity in local governments.

\subsection{Simultaneous top-down and bottom-up development}

A simultaneous bottom-up/top-down approach would ideally encourage international organisations (IOs) and national governments to engage with local actors directly at all points during the policymaking process. While IOs often cannot engage directly with local governments because of their international mandate, national level actors should be encouraged to include as many local actors as possible in their work. This is not without important challenges; inter-governmental co-operation is often tied to entrenched local political dynamics which make co-operation subject to the resolution of unrelated issues. This has been explored, for example, in the case of poverty alleviation programmes in Brazil (Fenwick, 2009). Local political issues which are beyond the realm of international organisations' spheres play an important role in determining the success or failure of policy, particularly when it comes to TOC and fragile states where the foundations for co-operation may be weak.

With this in mind these are some possible entry points that may help this approach to succeed:

1) National level governments must be encouraged by IOs to form an inclusive policy network when implementing a programme. This may include local government and other social actors.

2) Experts should be consulted in order to establish the possibility of local inter-governmental co-operation given the local environment.

3) Local assessments that involve actors on the ground as well as potential beneficiaries of the programme should be built into programme design and policy implementation. The challenge here is, once again, to reconcile IOs' international mandate with local needs.

\section{4. $\quad$ Peace operations based on better training and research}

Peace missions are a key opportunity to tackle TOC, but one which many peacekeeping forces are not fully trained to deal with. A shift from a confrontational strategy to a managerial one is a proactive way to minimise the harm that TOC can inflict on a peace process. It also helps to avoid criminalising certain key actors and thereby impairing the peace process.

This approach will require careful in-depth research into the forms and strategies that TOC uses in each of the areas where peacekeeping forces work. It will mean using experts in TOC to form a part of the peacekeeping strategy and to design and produce guidelines and tools to assist the forces on the ground. Such guidelines must be multi-disciplinary if peacebuilding actors are to have better chance of success by minimising the harm done by TOC. A harm-reduction strategy (Box 5.1) for managing TOC may have good results and, most importantly, create an environment where peace becomes a real possibility and allows for the creation of strong institutions that are better able to prevent TOC in the future. This policy could be an interesting model for developed nations trying to control demand for narcotics in their territory, while also having strong beneficial effects in producing and transit countries. This will be an important 
entry point for dealing with TOC in the future.

\section{5. $\quad$ Standardising definitions and information}

Much has been said about the desirability of evidence-based policymaking; this applies equally to the field of TOC. One of the most important challenges facing policymakers is the lack of data on costs, victims and other measurable factors related to TOC. Academics have long argued for the need to produce and publish better data on the size of criminal markets, the economic effects of TOC, its direct and indirect victims and a host of other factors associated with it. Today this is a distant reality. Data on TOC are sporadic and very localised at the best of times. While qualitative studies are of very high value, especially at the local level, there is a pressing need for more and better information on which to base policy decisions. There is still a lack of data on the activities of TOC, especially in fragile states where the infrastructure for data collection and analysis is often non-existent. States and international organisations must do more to produce and help others produce this information through funding initiatives and local partnerships. For example, a recent joint project between the UNODC and the Mexican National Institute of Statistics and Geography (INEGI in Spanish) aims to produce and improve data on crime and the justice system. There has also been a call for legal standardisation as conflicting definitions of human trafficking across national legislations are impairing cross-national studies and programmes (ICPC, forthcoming). 


\section{Case studies}

The following case studies illustrate the points made throughout this paper. Comparing TOC issues in three different continents allows us to identify common denominators of TOC in fragile states, which may help in future co-ordinated policymaking:

1. Tajikistan shows how entrenched TOC can become in a weak state, and how it may find symbiotic ways to function with local institutions so as to convert the country into a transit state.

2. Having stabilised following a civil war, El Salvador is today suffering from a peace process which did not focus adequately on institution building - it has now fallen victim to opportunistic TOC, and is a state which also acts as a transit route for illicit drugs.

3. Kenya offers a view of how TOC has exploited the state's weaknesses to create a regional hub of operation for many forms of illicit transnational crime.

\subsection{Tajikistan}

Sharing a 1 350-kilometre border with Afghanistan, Tajikistan has undergone profound internal turmoil, impoverishment and growing exposure to its neighbour's virtual monopolisation of world heroin production since the 1990s. This rugged country of around eight million people has become an example of a "narcostate", in which the revenues from trafficking drugs filter down to an extraordinary array of state and nonstate actors, including the security forces, political actors, warlords and insurgent Islamist groups. Tajikistan does not itself produce any notable quantities of drugs, while the US State Department classes its domestic consumption levels as "relatively low."

\section{Why is Tajikistan vulnerable to TOC?}

The transition of Tajikistan into a country marked by multiple forms of fragmentation and criminalisation within the context of an international flow of illicit products has a number of interlocking causes. Without doubt, Afghanistan's rise in the 1990s into a dominant position in the world heroin market, displacing Southeast Asia and producing $83 \%$ of all heroin in 2010, has been the necessary condition for the spread of TOC within Tajikistan. A porous border with Afghanistan (the two countries are separate by the Pyanj River, which can be easily crossed in most seasons) allows an estimated 90 tons of heroin each year to pass over to Tajikistan and other Central Asia Republics along what is called the "Northern route." This is the smallest of the three main arteries connecting Afghan poppy farms, largely in the south of the country, with markets in Europe and Asia. However, it is also the principal route through which heroin reaches Russia, which has the largest estimated consumption of the drug in the world, at around 70 tons a year.

Tajikistan is currently the poorest country in the post-Soviet Commonwealth of Independent States. Following the initial shock of the end of Communist planning, the country went on to suffer a steep decline in the size of its economy during the civil war of 1992 to 1997. It was during this period that the population of ethnic Tajiks straddling both sides of the border with Afghanistan began to play an important trafficking role, with the trade largely in the hands of independent peddlers and opportunists (many of them women heading their households as a result of the civil war). They often sold the product to dealers in Kyrgyzstan, and evaded controls by swallowing the heroin they were transporting.

By the late 1990s, Tajikistan had become a major hub for heroin trafficking, recording ever higher seizures and some of the world's lowest retail prices for the drug. It was at this stage that the post-war evolution of the country began to be marked by much deeper interaction between political power-holders and the drugs trade. As the scholar Johann Engvall (2006) has put it, "Organised crime has not even needed to fight its way into the system. Rather, it has followed as an integral part in the wake of the institutional reconstruction evoked by the war". 
With estimates suggesting that the drugs trade adds 30\% to official Tajik GDP - the highest share of drug trafficking to a national economy outside Afghanistan - large players immediately began to seek out profitmaking opportunities. The military skirmishes waged in 1999 and 2000 by the Islamic Movement of Uzbekistan (IMU), a pan-regional Islamist force, have been interpreted as a ploy to free up smuggling routes between Tajikistan and Kyrgyzstan. Although the force was largely destroyed during the overthrow of the Taliban regime in Afghanistan, with which the IMU had close ties, recent reports point to the militia's resurgence.

Meanwhile, the clan structure of political life and the presence of warlord leaders across a heavily fragmented Tajik polity - partly the result of the power-sharing accord which ended the civil war - make for numerous possible combinations between criminal factions and high-level political and military allies. Accusations against senior members of the security forces (including border guards and the Drug Control Agency), diplomats and leading political figures are numerous, though few cases against kingpins have actually reached the courts.

The difficulties in establishing the true dimensions and role of drug trafficking in perpetuating the fragility of the Tajik state are further compounded by the murkiness of recent events. Outbreaks of fighting and sporadic pact-making between the government of President Emomali Rakhmon and politico-military leaders in the east of the country may also have some connection to the drugs trade, not unlike the ethnic violence that erupted in Kyrgyzstan in 2010. Neither government nor rivals appear in the least interested in sealing the border with Afghanistan.

The importance of Tajikistan's strategic role in the region, particularly as regards the NATO mission in Afghanistan, has tended to override Western concerns over the criminalisation of the state. However, increasing violence between rival political camps, the institutional degradation spurred by the drugs trade and the consequent spillover into northern Afghanistan may serve to change these perceptions.

\subsection{El Salvador}

Central America is one of the world's most violent regions - its homicide rates are among the highest on the planet. The country is affected by the drug trade, crime and poverty $(58 \%$ of the population live on less than USD 2 a day). It has a homicide rate of about 66 deaths per 100000 habitants (UNODC, 2011a). Traffickers have carved paths through the region and crime and corruption remain a challenge for local governments.

\section{Why is El Salvador vulnerable to TOC?}

Central America's privileged geographical position has made it an ideal transit point for drugs on their way from the Andean region to the US. Very little of this cocaine is intended for local consumption, although there is evidence that gangs are being paid in kind with narcotics. A 2006 national survey conducted by the Organization of American States and the national drug observatory in El Salvador found that annual adult (ages 15-64) cocaine use prevalence was just $0.24 \%$ for cocaine and $0.17 \%$ for crack (OAS, 2006). TOC first appeared in El Salvador during its civil war (from 1980-1992). In 1979, a coup d'état saw a military junta come to power. As a response, in 1980 a number of left wing groups formed the Frente Farabundo Marti de Liberacion Nacional (FMLN in Spanish) to try to overthrow the junta. The state quelled this uprising with violence: death squads and torture were common, resulting in 80000 deaths, 9000 "missing" people and 1 million displaced and homeless people. Finally, after the intervention and monitoring by a United Nations contingent, a peace accord was signed in January 1992.

The consequences of the civil war can still be felt today. During the war drug traffickers made alliances with warring factions, trading weapons and financial support for the transport of drugs. Corruption seriously affected all levels of governance, facilitating bribing and alliances among criminal organisations and officials. El Salvador's fragile socio-economic situation was exacerbated during this time. A large share of the population witnessed, experienced or participated in the atrocities, resulting in widespread 
psychosocial trauma, "normalising" the violence in many communities. Conflict also introduced small arms and provided the training and mindset necessary for their use. About two million arms remain unregistered in the area (Rodgers et al., 2009).

During the civil war, large numbers of Central Americans sought refuge in the United States where they congregated in Hispanic urban neighbourhoods, particularly in southern California. These areas suffered from a serious gang problem, and the new immigrants found themselves targeted by locals. Partly as a defensive action, many young men either joined the existing gangs or formed their own. When the US began to tighten its immigration regime in 1996, many gang members were deported after being convicted of a crime, spreading the gang culture of southern California to Central America. While assessing the scale of gang presence is challenging, there are an estimated 70000 gang members in the seven countries of Central America today, with Honduras, El Salvador, and Guatemala being the worst affected (UNODC, 2007; Jütersonke et al., 2009).

\section{How is the state responding?}

Youth gangs - known as maras - are at the core of the government's crime agenda. They are readily associated with trafficking and the high homicide rates. The response to these challenges has been one of harsh repression. However, while some drug trafficking may involve gang members, the major channels seem to be in the hands of more sophisticated organised crime operations (Rodgers et al., 2009). El Salvador does not have a significant internal market for consumption of drugs. It is not clear how mostly landlocked urban gangs can benefit from an international drug trade which takes place mostly in coastal regions, by sea (UNODC, 2007). Rodgers and colleagues concretely challenge the sensationalist claims made about the power and organisation of the maras in recent times; they argue convincingly that their level of power and organisation has been overblown by certain media outlets and government agencies (Rodgers et al., 2009). This does not mean they do not represent a challenge, ${ }^{2}$ but it does call into question their importance for TOC.

The government response to the issue of rising crime rates and gang activity was traditionally a zero tolerance approach (mano dura), followed by a mano super dura programme in 2004. These policies not only further entrenched gangs within Salvadorean society (ICPC, forthcoming; Jütersonke et al., 2009), they also increased human rights abuses - including extra-judicial killings - and overall tensions in the region.

All this suggests that security policies that hinge on suppressing gang activity may not address the core crime issues confronting these countries. Violence appears to be endemic, and gang members represent the demographic group most at risk of both perpetrating and being victims of violence in any society.

After the clear failure of these overtly repressive policies a "second generation" of gang policies has come into effect. These include:

"UNDP-supported initiatives targeting at-risk youths involved in narcotics trafficking; interventions focusing on children associated with armed groups; urban programmes such as Municipalities without Weapons; public and private population health programmes targeting risk factors for violence; legislative reforms associated with international arms controls and civilian possession; and the National Commission of Citizen Security and Social Peace." (Rodgers et al., 2009: 18)

It is now evident that in order to address the roots of the problem long-term investment in socio-economic development and the rule of law must be prioritised rather than just confronting the symptoms through short-term law enforcement. This case further reinforces the need to re-assess current drug policies, as

\footnotetext{
${ }^{2}$ Gang members in Central America do appear to be involved in extortion, often "taxing" various forms of public transportation who wish to pass through their areas, or demanding payment from businesses enjoying their "protection".
} 
well as generating sound research into the actual state of TOC, especially in fragile settings where it may give rise to exaggerated or unrealistic ideas about the phenomenon.

\subsection{Kenya}

The Republic of Kenya is a key element of TOC in East Africa. The country has a population of nearly 41 million, representing 42 different peoples and cultures. Kenya's position on the east coast of Africa has made it a strategic location for trade for centuries. It is the economic hub of East Africa and a major tourist destination.

\section{What TOC elements are present in Kenya?}

The country is perceived as one of the most corrupt in the world, ranked $154^{\text {th }}$ on a list of 178 countries in the 2010 Transparency International Corruption Perception Index (Transparency International, 2011a). Close to $90 \%$ of Kenyans surveyed rated their country as being between corrupt and extremely corrupt, while only 8.5\% regarded it as slightly corrupt (Transparency International, 2010). However, the East Africa Bribery Index Report (Transparency International, 2011b) notes that Kenya recorded a slight bribery improvement, down to $28.8 \%$ from $31.9 \%$ in 2010. The consequences of organised crime for a democracy, particularly in developing and weak states, are most damaging where criminal organisations have penetrated the political domain in order to better consolidate or expand their economic opportunities and in order to limit competition (Allum and Siebert, 2003).

Kenya is an important transit country for narcotics (cocaine and heroin) distributed all over Africa. Indeed, at least ten major international drug trafficking networks, headed mainly by West Africans but also involving Kenyans, are responsible for the bulk of cocaine and heroin trafficked into and through the country. A recent trend has been the use of drug money to attain positions of influence, particularly in politics (Gastrow, 2011). Traffickers have established extensive international links to facilitate their global reach, something that the Kenyan law enforcement authorities have been unable to stem.

Kenya is the biggest market for counterfeit goods and contraband in East Africa. The counterfeit industry is sourced mainly from India and China and is worth about USD 913.8 million. For instance, approximately $25 \%$ of cigarettes smoked in the East African region are smuggled, causing governments to lose USD100 million in taxes (Kasita, 2009).

Mombasa port, which handles an average of 1700 containers a day, is a strategic asset for Kenya and its hinterland. It has become notorious for its abuse by organised crime networks for the smuggling of drugs, counterfeits, and other illicit commodities. According to a former bureau chief, N. Mutonya, "Mombasa is like a tunnel. All illicit business happens here, and it is controlled by traders supported by customs personnel and powerful people in government. Whoever controls the port controls the illicit business in Kenya" (Gastrow, 2011). Well-connected business people and top politicians have imposed a strong authority over business and smuggling activities at the port. They control networks involving police, customs and immigration officials, clearing and forwarding agents, among others (Gastrow, 2011).

The tourism industry is Kenya's leading foreign exchange earner, and the country's national parks and wildlife constitute a key attraction. Kenya's unique wildlife asset is under increasing threat due to the activities of international crime syndicates in the illegal wildlife trade. According to the Kenya Wildlife Society the illicit trade "involves networks of organised dealers, financiers, suppliers, brokers and merchants" (Gastrow, 2011). Ivory is the most sought-after item. A relatively new factor in ivory smuggling is the widespread involvement of East Asian nationals within Kenya, particularly Chinese groups. Crime syndicates made up of Kenyans and foreigners have established commercial reptile parks disguised as conservation or tourist-attraction centers. International criminal networks operating along the KenyaSomali border, and at Kismaayo port in Somalia, have diversified and now smuggle lion cubs to Europe, where they are ordered as pets (International Peace Institute, 2010). 
At least five to ten networks co-ordinate and organise human smuggling in northern Kenya and Nairobi. They tend to be headed by respected and well-known figures in society who operate within "legitimate" businesses. Their connections with top government and political figures contribute to the relatively low-risk environment in which they operate (Gastrow, 2011). Mombasa and the Eastleigh district in Nairobi constitute East Africa's hub for the smuggling of migrants, as well as for the trafficking of women and children for prostitution, the sex industry, and other forms of forced labour. This practice continues to grow in Kenya. In Mombasa young girls between the age of 10 and 15 are sold against their will into the sex industry and virtual slavery for a fee of about USD600. Arms traffickers have a sophisticated smuggling system that links Somalia with the United Nations refugee camp at Dadaab and Nairobi. Relatively small ad hoc criminal networks appear to be responsible for most of the small arms trafficked into and through Kenya. They often consist of Somali nationals who work with Kenyans and others. The smugglers often include other contraband in their activities, such as sugar, drugs, or counterfeit goods (Gastrow, 2011).

A US State Department report argues that Kenya is fast becoming a major money laundering hub (US Department of State, 2010). The report claims that Kenya's financial system may be laundering more than USD100 million each year; these funds include the proceeds from drugs and piracy. Major financial scandals have broken out without resulting in any prosecutions. Allegations have been made that relatives and associates of former President Moi siphoned off more than USD1.8 billion of government money into banks and acquisitions abroad (Kroll Associates UK, 2004). Charterhouse Bank, described as a "money laundering machine" (Nairobi Star, 2010), had its accounts frozen amidst allegations of tax evasion, fraud, and money laundering, including massive transfers into accounts abroad. The scandal involved prominent businesspersons and politicians, none of whom have been prosecuted.

\section{How is the state responding?}

At the national level some progress has been made. The former head of the Anti-Corruption Commission, John Githongo, uncovered and investigated acts of corruption worth close to USD 1 billion while in charge of the agency. After a period of exile he returned to Kenya and is today one of the foremost activists and local leaders in these matters. Recent money-laundering legislation has come into effect and it is hoped it will enable the Kenyan state to tackle this issue. 


\section{Conclusions and areas for further research}

TOC takes many forms in fragile states and is involved in a myriad of activities such as drug trafficking, natural resource trafficking, piracy and human trafficking. We have established three ways in which TOC operates in fragile states regardless of the illicit activity in question: 1) through local organisations with global reach, such as gangs that supply local demand for illicit goods; 2) as part of transnational logistical networks, such as Kenyan TOC groups who are involved in the international drug trade; and 3) as mere transit points for illegal goods (such as El Salvador within the cocaine trade or Tajikistan in the heroin market).

TOC affects a state's ability to deliver public goods and can ultimately undermine state legitimacy through corruption and cronyism. It can also compromise the effectiveness of peacekeeping operations, as well as creating conditions which will hamper the development of democratic institutions in the long term. The reasons for the presence of TOC in fragile states are varied and are related mainly to:

- the expansion of more fluid and dynamic criminal networks worldwide through the exploitation of global economic structures;

- the local political economy of fragile states that allows for TOC to operate there; and

- the social context of fragile states which can allow TOC, once established, to perpetuate its operations.

The main potential entry points for tackling TOC include a holistic approach to development which emphasises the rule of law and community-based action, as well as a change in the approach to TOC from peace missions and operations. Clearly much more time is needed to develop the ideas presented here to their full potential; however it is hoped that this paper will sow the seeds for developing solid, evidence-based discussion on a framework of action that specifically tackles TOC and much-needed future research into the behaviour, mechanisms of operation and consequences of TOC in fragile and conflict-afflicted states, as well as its relations with other international factors. 


\section{Bibliography}

Adams, T. M. (September, 2011), "Chronic Violence and Its Reproduction: Perverse Trends in Social Relations, Citizenship and Democracy in Latin America", Woodrow Wilson International Center for Scholars.

Albanese, J. S. (2010), Organized Crime in Our Times, 6th ed., Anderson Publishing, Cincinnati.

Allum, F. and Siebert R. (eds.) (2003), Organized Crime and the Challenge to Democracy, Routledge, London.

Anten, L., I. Briscoe and M. Mezerra (2012), The Political Economy of State-Building in Situations of Fragility and Conflict: From Analysis to Strategy, Conflict Research Unit, Netherlands Institute of International Relations 'Clingendael'.

Arias, E. D. (2006), Drugs \& Democracy in Rio De Janeiro: Trafficking, Social Networks, \& Public Security, The University of North Carolina Press.

Arias, E. D. and D. M. Goldstein (2010), Violent Democracies in Latin America, Duke University Press Books, Durham and London.

Ashdown, P. (2006), "Former High Representative, Bosnia and Herzegovina", in Rausch C. and E. Banar ed., Combating Serious Crimes in Postconflict Societies: A Handbook for Policymakers and Practitioners, United States Institute of Peace Press, Washington D.C.

Baker, B. (2009), Security in Post-Conflict Africa: The Role of Nonstate Policing, CRC Press, New York.

Block, A. A., and W. J. Chambliss (1981), Organizing Crime, Elsevier, New York.

Briscoe, I. (2011), What Makes Countries Vulnerable to Transnational Organised Crime?, Norwegian Peacebuilding Resource Centre, Oslo.

Bunker, R. J. and J. P. Sullivan (2011), "Integrating Feral Cities and Third Phase Cartels/Third Generation Gangs Research: The Rise of Criminal (Narco) City Networks and BlackFor" in Small Wars \& Insurgencies 22 (5): 764-86.

Ceccarelli, A. (2007), "Clans, Politics and Organized Crime in Central Asia", in Trends in Organized Crime, 10 (3), 19-36.

Cockayne, J., and A. Lupel (2011), Peace Operations and Organized Crime: Enemies or Allies? . Routledge, London.

Cockayne, J. and C. Kavanagh (2011), "Flying Blind? Political Mission Responses to Transnational Threats", in 2011 Annual Review of Political Missions, NYU Center for International Cooperation, New York.

Cockayne, J. and D. R. Pfister (2008), Peace Operations and Organised Crime, Geneva Papers, GCSP and International Peace Institute (IPI), Geneva.

Cornell, S. (2005), "Narcotics, Radicalism, and Armed Conflict in Central Asia: The Islamic Movement of 
Uzbekistan", in Terrorism and Political Violence, 17 (4): 619-39.

Cornell, S. (2007), "Narcotics and Armed Conflict: Interaction and Implications", in Studies in Conflict \& Terrorism 30 (3): 207-27.

Dijk, van J. (2007), "Mafia Markers: Assessing Organized Crime and Its Impact Upon Societies", in Trends in Organized Crime, 10 (4): 39-56.

Dixit, A. (2004), Lawlessness and Economics, Princeton, Princeton University Press.

Ellis, S. (2009), "West Africa's International Drug Trade", in African Affairs, 108 (431): 171-96.

Engvall, J. (2006), "The State under Siege: The Drug Trade and Organised Crime in Tajikistan", in Europe-Asia Studies 58 (6): 827-54.

Farah, D. (2011a), "Organized Crime in El Salvador: The Homegrown and Transnational Dimensions" in Working Paper Series on Organized Crime in Central America, Woodrow Wilson Center for International Scholars, Washington DC.

Farah, D. (2011b), Transnational Criminal Threats in El Salvador: New Trends and Lessons From Colombia, Western Hemisphere Security Analysis Center of Florida International University, Miami.

Felbab-Brown, V. (2011), Bringing the State to the Slum: Confronting Organized Crime and Urban Violence in Latin America, Latin America Initiative at Brookings, Washington D.C.

Fenwick, T. (2009), "Avoiding Governors: The Success of Bolsa Familia", in Latin American Research Review 1, 44: 102-131.

Gambetta, D. (1996), The Sicilian Mafia: The Business of Private Protection, Harvard University Press, Harvard.

Garay-Salamanca, L. J., E. Salcedo-Albarán and I. de León-Beltrán (2010), Illicit Networks Reconfiguring States: Social Network Analysis of Colombian and Mexican Cases, Fundación Método, Bogotá.

Gastrow, P. (2011), Termites at Work: Transnational Organized Crime and State Erosion in Kenya, International Peace Institute, New York.

Gavrilis, G. (2009), "The Tajik Solution: A Model for Fixing Afghanistan", in Foreign Affairs, November, 2009.

GCDP (Global Commission on Drug Policy) (2011), War on Drugs, GCDP, Rio de Janeiro.

Harriott, A. (2007), Organized Crime and Politics in Jamaica. Breaking the Nexus, Canoe Press, Kingston, Jamaica.

Hernandez, D. (2011), "Cartel Corruption Reaches into the Ranks of U.S. Border Agents, Officials Say", in Los Angeles Times, June 13, 2011, at http://latimesblogs.latimes.com/laplaza/2011/06/bordercustoms-hearing-corruption-agents.html.

Hobbs, D. (1988), "Professional and Organized Crime in Britain", in Maguire M., R. Morgan and R. Reiner eds., The Oxford Handbook of Criminology, Clarendon, Oxford, 441-68.

ICPC (International Centre for the Prevention of Crime) (forthcoming), 2012 International Report - Crime 
Prevention and Community Safety: Trends and Perspectives, ICPC, Montreal.

IMF (International Monetary Fund) (2011), Kenya: Poverty Reduction Strategy Paper, Progress Report, IMF, Washington D.C.

INEGI (Instituto Nacional de Estadísticas y Geografía) (2011), Seguridad Pública y Justicia 2010: Principales Indicadores 2010, INEGI, Mexico

Inglehart, R. and C. Welzel (2009), "How Development Leads to Democracy - What we Know About Modernization", in Foreign Affairs, March/April 2009, 33-48.

International Crisis Group (2010), "Dangerous Little Stones: Diamonds in the Central African Republic", ICG, Brussels.

International Crisis Group (2011), "Tajikistan: The Changing Insurgent Threats", in Asia Report, 205, ICG, Brussels.

Jütersonke, O., Muggah, R. and D. Rodgers (2009), "Gangs and Violence Reduction in Central America", in Security Dialogue, October 2009, 40 (4-5): 1-25.

Kasita, I. (2009), "Uganda Loses \$105 Million to Smuggling", in New Vision, December 2, 2009.

Kaufmann, D. (2003), "Governance Redux: The Empirical Challenge", in World Bank Policy Research Working Paper .

Kaufmann, D. and A. Kraay (2002), "Growth without Governance", World Bank Policy Research Working Paper 2928.

Kenney, M. (2009), "Turning to the 'Dark Side': Learning in Illicit Networks", in Kahler M. (ed.), Networked Politics: Agency, Power, and Governance, Cornell University Press..

Kleiman, M. (2011), "Surgical Strikes in the Drug Wars", in Foreign Affairs, 90 (5).

Kroll Associates UK (2004), Projet KTM, Consolidated Report Kroll Associates. UK.

Leslie, G. (2010), Confronting the Don: the Political Economy of Gang Violence in Jamaica, Small Arms Survey, Geneva.

Levinson, M. (2006), The Box: How the Shipping Container Made the World Smaller and the World Economy Bigger, Princeton University Press, New Jersey.

Lopez, C. (2010), Y Refundaron la Patria, Random House Mondadori, Bogotá.

Manrique, L. E. (2006), "Un poder paralelo: el crimen organizado en América Latina", in Boletín Elcano, 84 (9).

Michael, K., (2008), "The Paradigm Shift in Transnational 'Organised Crime'", LEGL960: Issues in Transnational Organised Crime, at http://works.bepress.com/kmichael/195

Migdal, J. (2001), State in Society: Studying How States and Societies Transform and Constitute One Another, Cambridge University Press, Cambridge.

Ministry of Tourism, Kenya (2006), "KWS Investigates Somalia Lion Cub Smuggling Ring," at 
www.tourism.go.ke/ministry.nsf/pages/news_29Nov06_03.

Morselli, C., M. Turcotte and V. Tenti (2010), The Mobility of Criminal Groups, Ottawa, ON: Public Safety Canada.

Muggah, R. (2009), Security and post-conflict reconstruction: dealing with fighters in the aftermath of war, Routledge, New York.

Nairobi Star (2010), "Kenya: State Deep in Charterhouse Conspiracy", Nairobi Star, 1 October 2010 at http://allafrica.com/stories/201010010131.html

Nordstrom, C. (2007), Global Outlaws: Crime, Money, and Power in the Contemporary World, University of California Press, Berkeley and Los Angeles.

OAS (Organization of American States) (2006), El Salvador: Evaluation of progress in drug control 20052006, Inter-American Drug Abuse Control Commission (CICAD), OAS, Washington, DC.

OECD (2011a), International Engagement in Fragile States: Can't We Do Better?, OECD Publishing.

OECD (2011b), Supporting Statebuilding in Situations of Conflict and Fragility: Policy Guidance, DACGuidelines and Reference Series, OECD Publishing.

OECD (2012), Think Global, Act Global: Confronting global factors influencing conflict and fragility, OECD Publishing, available at www.oecd.org/dac/conflictandfragility/globalfactors.htm.

Ohlson, T. and M. Söderberg Kovacs (2009), "Peace Through Democracy? The Challenges of Postwar Democratization in Weak and War-Torn States", in Swain A., Amer R. and J. Öjendal (eds.), The Democratization Project: Opportunities and challenges, Anthem Press, London, 165-182.

Olson, E. L. (2012), Considering New Strategies for Confronting Organized Crime in Mexico, Woodrow Wilson Centre Mexico Institute, Washington D.C.

Paoli, L. (2002), "The Paradoxes of Organized Crime", in Crime, Law and Social Change, 37: 51-97.

Paoli, L., I. Rabkov, V.A. Greenfield and P. Reuter (2007), "Tajikistan: The Rise of a Narco-State", in Journal of Drug Issues, 37 (4): 951-80.

Putnam, R. D. (2000), Bowling Alone: The Collapse and Revival of American Community, Simon and Schuster, New York.

Quinonez, J. et al. (2010), Una Aproximación a La Problemática De La Criminalidad Organizada En Las Comunidades Del Caribe Y De Fronteras, 1st ed., Instituto de Estudios Estratégicos y Políticas Públicas, Managua.

Reeves, M. (2010), “A Weekend in Osh”, London Review of Books, July 8, 2010.

Reno, W. (1995), Corruption and State Politics in Sierra Leone, Cambridge University Press, Cambridge.

Reuter, P. (1983), Disorganized Crime: The Economics of the Visible Hand, MIT Press, Cambridge, MA.

Reuter, P. and V. Greenfield (2001), "Measuring Global Drug Markets", in World Economics 2 (4): 159-73.

Reuter, P. and F. Trautmann, (2009), "A Report on Global Illicit Drug Markets 1998-2007", European 
Commission, Netherlands.

Rocha, J.L. (2006), "Nicaraguan Youth Gangs: From Throwing Stones to Smoking Rocks", in Revista Envío, 302, September 2006.

Rodgers, D., R. Muggah and C. Stevenson (2009), "Gangs of Central America: Causes, Costs and Interventions", in Small Arms Survey Occasional Papers, May 2009, Occasional Paper 23, Geneva.

Skaperdas, S. (2001), "The Political Economy of Organized Crime: Providing protection when the state does not", in Economics of Governance (2001), 2: 173-202.

Strazzari, F. (2008), “L'Oeuvre au Noir: the Shadow Economy of Kosovo's Independence”, in International Peacekeeping, 15 (2): 155-170.

Tilly, C. (1985), "War Making and State Making as Organized Crime", in Evans P., Rueschemeyer D. and T. Skocpol (eds.), Bringing the State Back In, Cambridge University Press, Cambridge.

Torres, C. (2010), "El pueblo mas robado de Colombia", in El Espectador, September 112010.

Transparency International (2010), "Kenya: Burundi Most Corrupt Country in East Africa as its Revenue Authority Tops List of Corrupt Institutions", in Transparency International 22 July 2010, at www.transparency.org/news_room/latest_news/press_releases_nc/2010/2010_07_22_ti_kenya_ea bi (accessed on February 5, 2012).

Transparency International (2011a), Corruption Perception Index 2011, Transparency International, Dublin.

Transparency International (2011b), East African Bribery Index 2011, Transparency International, Dublin, at www.transparency.org/files/content/pressrelease/20111020_Tanzania_EABI2011_EN.pdf

United Nations, General Assembly (2004), Report of the High-Level Panel on Threats, Challenges and Change, A More Secure World: Our Shared Responsibility, UN, New York.

UNDCP (United Nations International Drug Control Program) (1997), World Drugs Report, UNDCP, Vienna.

UNDP (United Nations Development Program) (2012), Governance for Peace - Securing the Social Contract, UNDP, New York.

UNDPKO (United Nations Department of Peacekeeping Operations) (2008), United Nations Peacekeeping Operations Principles and Guidelines, Department of Field Support, UNPKO, New York.

UNODC (United Nations Office on Drugs and Crime) (2007), Crime and Development in Central America, UNODC, Vienna.

UNODC (2008), UNODC Strategy 2008-2011: Towards Security and Justice for All: Making the World Safer from Crime, Drugs and Terrorism, UNODC, Vienna.

UNODC (2010), The Globalization of Crime: A Transnational Organized Crime Threat Assessment, UNODC, Vienna. 
UNODC (2011a), 2011 Global Study on Homicide, UNODC, Vienna.

UNODC (2011b), World Drugs Report 2011, UNODC, Vienna.

US Department of State (2010), Bureau of International Narcotics and Law Enforcement Affairs (2010). 2010 International Narcotics Control Strategic Report, US Department of State, Washington DC.

US Department of State (2011), "Tajikistan Country Report", in International Narcotics Control

Strategy Report, US Department of State, Washington DC.

Varese, F. (2011), "Mafia Movements: A Framework for Understanding the Mobility of Mafia Groups", in Global Crime, 12 (3): 218-31.

Varese, F. (2000), "Pervasive Corruption", in Ledeneva A. and M. Kurkchiyan (eds.), Economic Crime in Russia, Kluwer Law International, London, 99-111

West, J. (2006), "The Political Economy of Organized Crime and State Failure: The Nexus of Greed, Need and Grievance", in Innovations: A Journal of Politics, 6.

World Bank (2011), World Development Report 2011: Conflict, Security and Development, World Bank, Washington DC. 
